\title{
内耳電位とホルモン
}

\author{
森望

\section{Role of Hormones in the Inner Ear}

\author{
Nozomu Mori \\ (Kagawa Medical University)
}

\begin{abstract}
Recent studies of hormones in the inner ear are described. The possibility that hormones act on the cochlea through the adenylate cyclase-cyclic AMP system and through the regulation of blood flow in the cochlea is dicussed, though no direct evidence supporting this hypothesis yet exists. The action of hormones on the vestibule is still unknown. In the endolymphatic sac, direct evidence supporting the action of catecholamines on the endolymphatic sac has recently been obtained. Our recent study revealed that catecholamines change the oxygen-dependent positive DC potential in the endolymphatic sac of the guinea pig in a reversible manner. The involvement of aldosterone in regulating the functions of the endolymphatic sac has also been suggested. It is assumed that the endolymphatic sac may be an important tissue for hormonal regulation in the inner ear.
\end{abstract}

Key words: inner ear, potential, hormone, adenylate cyclase

内耳機能がホルモンにより調節されるという 考えは, 内耳疾患の臨床症状・所見の変化を説 明する際に非常に興味深い仮説と思われる.内 耳とアミノ配糖体や利尿剂に対する薬理学的反 応が類似している腎臓では，各種のホルモンの 関与が知られている. Aldosterone, Atrial natriuretic factor, Vasopressin, Catecholamines, Prostaglandins, Renin, Angiotensins などがあげられる．今までホルモンの内耳電位 に対する効果を調べた報告1)2) はあるが，ホル モンの内耳機能への直接的な関与を示唆した報 告はなかった. 最近, 内耳に打けるホルモンレ セプターに関する報告がされるようになってき た3)4).内耳に抢けるホルモンの役割につき, 特に内耳電位への役割に関して, われわれの研
究結果も含めて最近の研究報告から考察してみ たい.

\section{螖牛}

ホルモンの関与が示唆される系として，まず, Adenylate cyclase-cyclic AMP system が考え られる. 蝸牛に Adenylate cyclase が存在する ことは組織化学的5)6) および生化学的研究7) 12) により証明されており，さらに，血管条におい てその活性が強いことが報告されている7). 内 耳に拈ける Adenylate cyclase-cyclic AMP system を賦活化するホルモンとして Catecholamines ${ }^{8) 11)}$ と, Vasopressin ${ }^{8)}$ が報告されてい る. Catecholamines ${ }^{8) 11)}$ は $\beta$ receptor を介し て作用をおこすとされている。これに対して Catecholamines ${ }^{10)} \cdot$ Vasopressin ${ }^{10111)}$ は血管条 
の Adenylate cyclase の活性を上昇させないと する報告もあり，一定した結果は得られていな い. Isoproterenol が，小さいが有意の endocochlear potential (EP) の上昇を起こしたと する報告13) もあるが，われわれの抏こなった 実験では，外リンパ灌流 (5 mM)（図 1 ）およ び静脈投与 $(12.5 \mu \mathrm{g} / \mathrm{kg})$ （図 2 ）でも有意な上 昇は認めなかった. Vasopressin では $10 \mu \mathrm{M}$ 以 上の高濃度の外リンパ灌流で可逆的に EP の低 下をきたした ${ }^{14)}$ が，静脈投与では二倍以上の 著明な血圧上昇を掞こす $40 \mathrm{mU}$ の投与にて数 \%の一過性の EP の低下をおこすのみであり， 生理的な状態で役割をもっているとするのは， まだ，疑問があると思われる。

最近, Doi et al. ${ }^{15)}$ は Adenylate cyclasecyclic AMP system を賦活する物質である Forskolin の外リンパ灌流にて，可逆的に $20 \mathrm{mV}$ 程度の $\mathrm{EP}$ の上昇を起こすと報告した。ホルモ

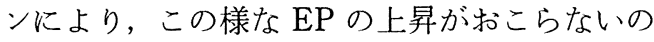
は, Adenylate cyclase-cyclic AMP system が 生理的な役割を持っていないのか, Catecholamines $\cdot$ Vasopressin 以外のホルモンが関与し
ているのかのいずれかと推察される.

Aldosterone の Receptor が内耳に存在する ことが報告され4), Aldosterone の Antagonist である Canrenoate の外リンパ灌流により EP が可逆的に低下することが示された ${ }^{16)}$.

Aldosterone が EP に対して何らかの作用を持 っている可能性が考えられるが，Canrenoate の静脈内投与では著明な低下を示さなかった17) ので, Aldosterone が生理的な役割を持ってい るとするのは困難であると思われる．

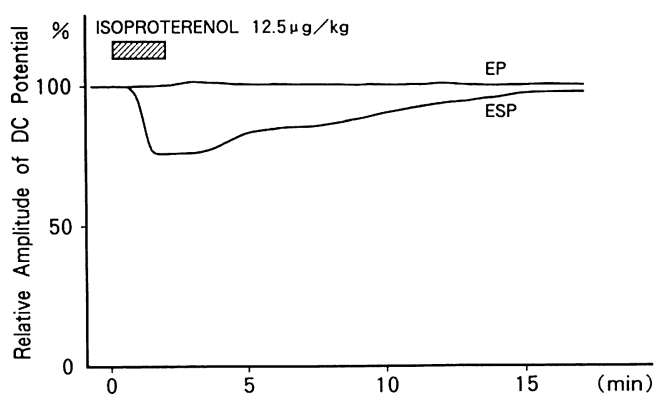

図 2 Isoproterenol $(12.5 \mu \mathrm{g} / \mathrm{kg})$ の静脈内投与に対 する EP (Endocochlear potential) と ESP (Endolymphatic sac DC potential) への効果
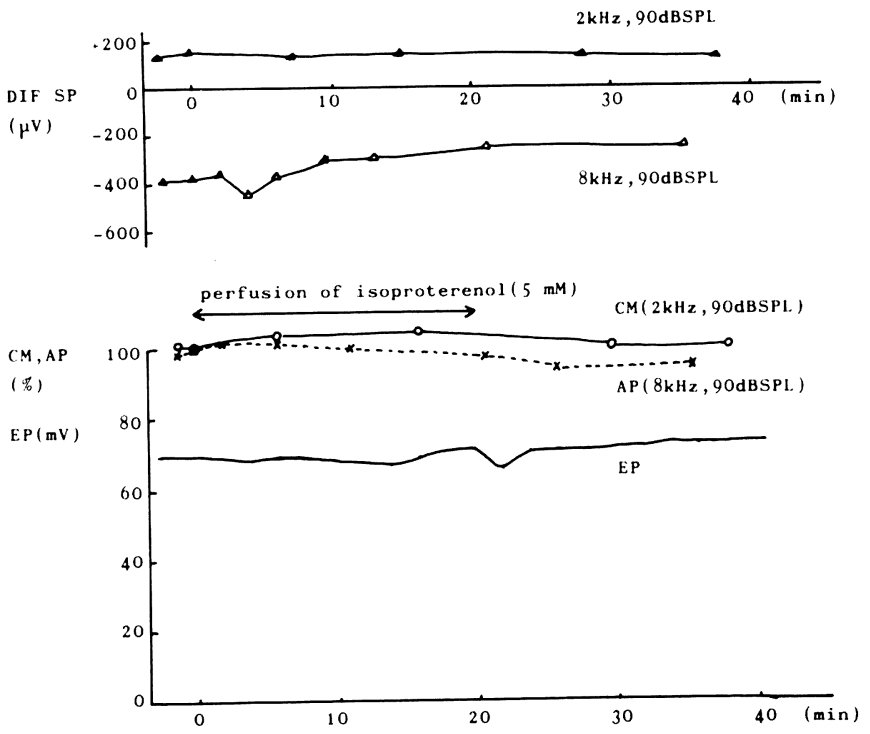

図 1 Isoproterenol (5 mM)の外リンパ灌流に対する蝸牛電位 (EP : Endocochlear potential, CM : Cochlear microphonics, SP : Summating potential, AP : Action potential) の反応 
血管系を介したホルモンの内耳への影響とし $\tau$, Catecholamines $(\alpha \text { receptor })^{2) 18)}$, Angiotensin II ${ }^{19)}$, Prostaglandins ${ }^{2021)}$ が考えられる. Catecholamines は血管収縮により血流の低下 を拈こし，Action potentioal (AP) の低下を拉 こすとの報告がある2). Angiotensin II は全身 血圧の上昇により二次的に蝸牛血流の増加をき たすと報告されている19). Prostaglandins に関 しては血管条・らせん勒帯において，血管拡張 物質とされている Prostacyclin $\left(\mathrm{PGI}_{2}\right) \cdot$ Prostaglandin $\mathrm{E}_{2}\left(\mathrm{PGE}_{2}\right)$ の生成が行われていると の報告がされている20). アスピリンにより Prostaglandins 生成の抑制が抗こり，また，音響 刺激によりその生成が充進することが報告され て抢り, Prostaglandins が蝸牛血流を制御して いる可能性が指摘されている20).

\section{前庭}

蝸牛に比べて，前庭系ではホルモンに関する 研究は少ないが, Adenylate cyclase の活性が 前庭にも存在することが報告されている922223). また，前庭においても Prostaglandins ( $\mathrm{PGI}_{2}$, $\left.\mathrm{PGE}_{2}\right)$ が，主に dark cells で生成されていると の報告がある24)。最近，内耳の圧変化が抗利尿 ホルモンであるVasopressin の分泌を制御して 掞り，内耳に圧レセプターが存在する可能性を 示す報告がなされた25).

\section{内リンパ囊}

今まで，内リンパ震に打けるホルモンの関与 に関する研究は, ほとんど,なされていなかっ た. Mees ${ }^{26)}$ が Adenylate cyclase の活性の存在 を示した研究があるのみであった。最近, 内リ ンパ霬中間部に酸素依存性の陽性直流電位 (+ 15〜20 mV) の存在が Amano ら 27) により報告 された。この電位 (endolymphatic sac DC potentioal : ESP)の発生源は，まだ不明である が, 能動イオン輸送がその発生に関与している と考えられている2728).

われわれの最近の研究から, Catecholamines が可逆的に ESP $\beta$ 作用により低下させるこ

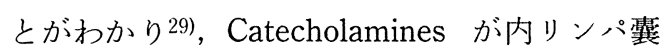

の機能を制御していることが考えられる、図 2

・図 3 にCatecholamines の ESP に対する作用 を示した. 特に Epinephrine は少量で変化を起 こすことから 29) 生理的に作用している可能性 が充分考えられる. また, Aldosterone の Antagonist である Canrenoate により, ESP が低 下し，また，Aldosterone の前投与により， Canrenoate による ESP の低下が抑制されるこ と30)311 から Aldosterone の内リンパ霬における 何らかの作用が存在することが推察される.こ れらの研究から, 内リンパ震においてホルモン が重要な役割をしていることが考兄られる.

\section{おわりに}

内耳に拈いては, 腎蔵のように各種のホルモ ンの役割が明確にはなっていないが, 最近の研 究から, 少しずつ, 何らかのかたちでホルモン が関係しているらしいことがわかってきている。 蝸牛に打いては, Adenylate cyclase-cyclic AMP system におけるホルモンの関与と血流 に対するホルモンの関与がある. Adenylate cyclase-cyclic AMP system を活性化すると EP の上昇を示すことがわかっているが， Adenylate cyclase を蝸牛において活性化する ものとして, 候補に上がっているホルモンでは 一定した EP の上昇はみられていないので, Adenylate cyclase を介したホルモンの蝸牛で の生理的役割は，まだ疑問であると言わざるを 得ない、また，血流を介したホルモンの役割に ついても, 直接的なホルモンの関与はまだ証明

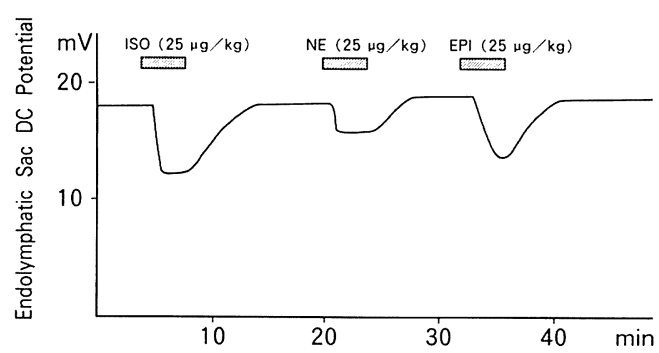

図 3 ESP の Catecholamines (ISO : Isoproterenol, NE : Norepinephirine, EPI : Epinephrine) に よる変化 
されていない，前庭系に関してはまだ，研究 も少なく，ホルモンの関与については全く不明 であり, 今後の研究が待たれている.内リンパ 噀における研究は少ないが，最近のわれわれの 研究で, Catecholamines が内リンパ囊直流電 位を少量で可逆的に変化させることがわかり, 内リンパ慗における Catecholamines の役割の 重要性が示唆される.内耳におけるホルモンの 役割に関しては，さらに研究されなければなら ない分野であり, 今後, 多方面からの研究の発 展が望まれる。

稿を終えるにあたり, 御指導を賜った大阪大学医 学部耳鼻咽喉科教室 松永亭教授, 香川医科大学耳 鼻咽喉科教室 酒井俊一教授, 奈良医科大学耳鼻咽 喉科教室 松永喬教授に深甚なる謝意を表します。 また，研究にご協力いただきました土井勝美先生， 太田和博先生, 由良和代先生, 魚住成彦先生に深く 感謝いたします。

\section{参考文献}

1）平島直子, 森満 保, 中島恒彦: Aldosterone, Aldactone の Cochlear Microphonics に及活す 影響. 耳喉 $45:$ 579 583, 1973.

2) Muchnik C, Hildesheimer M, Nebel L, et al : Influence of catecholamines on cochlear action potentials. Arch Otolaryngol $109: 530 \sim 532$, 1983.

3) Lamprecht J and Meyer zum Gottesberge AM : The presence and localization of receptors for atrial natriuretic peptide in the iner ear of the guinea pig. Arch Otorhinolaryngol $245: 300 \sim$ 301, 1988.

4) Rarey K and Luttge WG : Presence of type I and tyepII/IB receptors for adrenocorticosteroid hormones in inner ear. Hearing Res $41: 217 \sim 222,1989$.

5) Zajic G, Anniko $M$ and Schacht J : Cellular localization of adenylate cyclase in the developing and mature inner ear of the mouse. Hearing Res $10: 249 \sim 261,1983$.

6) Mees $\mathrm{K}$ : Cytochemical localization of adenylcyclase in the lateral wall of the inner ear. Arch Otorhinolaryngol $240: 55 \sim 61,1984$.
7) Ahlstrom $P$, Thalmann I, Thalmann R, et al : Cyclic AMP and adenylate cyclase in the inner ear. Laryngoscope $85: 1241 \sim 1258,1975$.

8) Zenner HP and Zenner B : Vasopressin and isoproterenol activate adenylate cyclase in the guinea pig inner ear. Arch Otorhinolaryngol $222: 275 \sim 283,1979$.

9) Bagger-Sjöback D, Filipek CS and Schacht J : Characteristics and drug responses of cochlear and vestibular adenylate cyclase. Arch Otorhinolaryngol $228: 217 \sim 222,1980$.

10) Tran Ba Huy $P$, Servin $F$, Ohresser $M$, et al : Adenylate cyclase in guinea pig stria vascularis. Biochemical characteristics and stimulation tests. Acta Otolaryngol (Stockh) $91: 9 \sim 14,1981$.

11) Schacht J : Hormonal regulation of adenylate cyclase in the stria vascularis of the mouse. Hear Res $20: 9 \sim 13,1985$.

12) Koch $T$ and Zenner HP : Adenylate cyclase and G-proteins as a signal transfer system in the guinea pig inner ear. Arch Otorhinolaryngol $245:$ 82 87, 1988.

13) Feldman AM : Cochlear biochemistry. Pharmacology of Hearing Experimental and Clinical Bases (ed by Brown RD and Daigneault EA). pp 71, John Wiley \& Sons, New York, 1981.

14) Mori $N$, Ohta $K$ and Matsunaga $T$ : The effect of vasopression upon the cochlear potentials in the guinea pig. Acta Otolaryngol (Stockh) $101: 217 \sim 223,1986$.

15) Doi $\mathrm{K}$, Mori $\mathrm{N}$ and Matsunaga $\mathrm{T}$ : Effects of forskolin and 1, 9-dideoxy-forskolin on cochlear potentials. Hearing Res $45: 157 \sim 164,1990$.

16）脇園茂樹, 小宗静男, 久 和孝, 他：カンレ, 酸カリウムの蝸牛内電位打上び蛤牛内リンパイ オン濃度に及淁す影響について。目鼻 93 ： 373 380, 1990.

17) Mori $N$, Uozumi $N$, Yura $K$, et al : The difference in endocochlear and endolymphatic sac d.c. potentials in response to furosemide and canrenoate as diuretics. Eur. Arch Otorhinolaryngol $247: 371 \sim 373,1990$.

18) Carrasco VN, Prasma J, Faber JE, et al : 
Cochlear microcirculation. Effect of adrenergic agonists on arteriole diameter. Arch Otolaryngol Head Neck Surg 116 : 411 417, 1990.

19) Wright JW, Dengerink HA, Miller JM, et al : Potential role of angiotensin II in noise-induced increases in inner ear blood flow. Hearing Res $17: 41 \sim 46,1985$.

20) Escoubet B, Amsallem P, Ferrary E, et al : Prostaglandin synthesis by the cocchlea of the guinea pig. Influence of aspirin, gentamicin, and acoustic stimulation. Prostaglandins 29 : 589 599, 1985.

21) Tran Ba Huy P, Ferrary E, Escoubet B, et al : Strial prostaglandins and leukotrienes. Acta Otolaryngol (Stockh) $103: 558 \sim 566,1987$.

22) Paloheimo $S$ and Thalmann $R:$ Influence of "loop" diuretics upon $\mathrm{Na}^{+} \mathrm{K}^{+}$-ATPase and adenylate cyclase of the stria vasuclaris. Arch Otorhinolaryngol $217: 347 \sim 359,1977$.

23) Marks SC and Schacht J : Effects of ototoxic diuretics on cochlear $\mathrm{Na}^{+} \mathrm{K}^{+}$-ATPase and adenylate cyclase. Scand Audiol Suppl 14 : $131 \sim 138,1981$.

24) Ferrary E, Bernard C, Sterkers O, et al : Prostaglandins in the semicircular canal of the frog. Hearing Res $26: 139 \sim 144,1987$.

25) Bartoli E, Satta A, Melis F, et al : Volume receptors in guinea pig labyrinth; relevance with respect to $\mathrm{ADH}$ and $\mathrm{Na}$ control. Am J Physiol 257 : F341 346, 1989.

26) Mees $\mathrm{K}:$ Die hormonelle Steuerung des Innenohrs. Fiktion oder Realitat? Laryng Rhinol Otol $63:$ 626 632, 1984.

27) Amano $H$, Orsulakova $A$ and Morgenstern $C$ : Intracellular and extracellular ion content of the endolymphatic sac. Arch Otorhinolaryngol $237: 273 \sim 277,1983$.

28) Mori $N$, Ninoyu $O$ and Morgenstern $C$ : Cation transport in the ampulla of the semicircular canal and in the endolymphatic sac. Arch Otorhinolaryngol $244: 61 \sim 65,1987$.

29) Mori N, Uozumi $N$ and Sakai S : Catecholamines depress the endolymphatic sac DC potential in the guinea pig. Am J Physiol 259, 1990.

30）森望, 由良和代, 魚住成彦, 他：内リンパ 䈊におけるアルドステロンの役割について．耳 鼻臨床 補37：104～106, 1990.

31) Mori N, Yura K, Uozumi N, et al : Effects of aldosterone antagonist on the DC potential in the endolymphatic sac. Ann Otol Rhinol Laryngol 99, 1990.

$$
\left(\begin{array}{l}
\text { 連絡先 : 森 望 } \\
\text { 干7761-07 香川県木田郡三木町池戸1750-1 } \\
\text { 香川医科大学耳鼻咽喉科学教室 }
\end{array}\right)
$$

